\title{
PPARy Expression in Eutopic and Ectopic Endometrium of Reproductive Age Women with Endometriosis
}

\section{Ekspresi Reseptor PPARy Endometrium Eutopik dan Ektopik pada Penderita Endometriosis Usia Reproduksi}

\author{
Adya F Dilmy, Muharam Natadisastra, Kanadi Sumapradja \\ Division of Reproductive Immunoendocrinology and Infertility \\ Department of Obstetrics and Gynecology \\ Faculty of Medicine University of Indonesia/ \\ Dr. Cipto Mangunkusumo Hospital \\ Jakarta
}

\begin{abstract}
Objective: To evaluate the expression of PPARy receptor and to compare its expression in eutopic and ectopic endometrium in women with endometriosis.

Method: This is a cross sectional study. Ten female subjects with endometriosis that underwent laparoscopy or laparotomy who fulfilled the inclusion criteria were recruited by consecutive sampling Two samples were taken, eutopic endometrium and ectopic endometrium from endometriosis cyst wall during surgery of each subject. PPARy expression was examined by two-step RT-qPCR. Our data was statistically examined using the paired t-test and Pearson's correlation test.

Result: PPARy was found to be expressed in eutopic and ectopic endometrium of women with endometriosis using the RT-qPCR method. The expression of PPARy was not statistically different in eutopic and ectopic endometrium (1.16 relative fold vs 1.25 relative fold; $\mathrm{p}=0.26$ ). By Pearson's correlation there was a weak positive correlation between PPARy expression of eutopic and ectopic endometrium $(\mathrm{r}=0.16)$.

Conclusion: PPARy was detected by two-step RT-qPCR in eutopic and ectopic endometrium of women with endometriosis. Semiquantification of PPARy expression showed that there was no significant difference between PPARy expression in eutopic and ectopic endometrium of women with endometriosis. There was a weak positive correlation between PPARy expression in eutopic and ectopic endometrium of women with endometriosis
\end{abstract}

[Indones J Obstet Gynecol 2015; 3-4: 200-205]

Keywords: endometriosis, PPARy, two-step RT-qPCR

\begin{abstract}
Abstrak
Tujuan: Menilai keberadaan reseptor PPARy serta membandingkan ekspresi reseptor PPARy pada endometrium eutopik dan ektopik pada penderita endometriosis.

Metode: Penelitian ini merupakan penelitian potong lintang (cross sectional). Sepuluh subjek penderita endometriosis yang menjalani laparoskopi atau laparotomi, yang masuk dalam kriteria penerimaan direkrut menggunakan consecutive sampling. Diambil dua sampel, yakni endometrium eutopik dan endometrium ektopik yang berasal dari dinding kista endometriosis saat dilakukan pembedahan, kemudian dilihat ekspresi reseptor PPARy dengan two-step RT-qPCR. Ekspresi masing-masing sampel diuji statistik dengan uji t berpasangan dan tes korelasi Pearson
\end{abstract}

Hasil: Didapatkan ekspresi reseptor PPARy pada endometrium eutopik dan ektopik penderita endometriosis dengan metode RT-qPCR Ekspresi reseptor PPARy endometrium eutopik dan ektopik didapatkan secara statistik tidak berbeda bermakna (1.16 lipatan relatif vs 1.25 lipatan relatif; $p=0.26$ ). Pada uji korelasi Pearson didapatkakan korelasi positif lemah antara ekspresi PPARy pada endometrium eutopik dan ektopik ( $r=0.16)$.

Kesimpulan: Tampilan reseptor PPARy pada endometrium eutopik dan ektopik penderita endometriosis didapatkan dengan metode twostep RT-qPCR. Dengan semikuantifikasi ekspresi reseptor PPARy tidak didapatkan perbedaan antara ekspresi reseptor PPARy pada endometrium eutopik dan ektopik pada penderita endometriosis. Terdapat korelasi positif lemah antara ekspresi reseptor PPARy pada endometrium eutopik dan ektopik pada penderita endometriosis.

[Maj Obstet Ginekol Indones 2015; 3-4: 200-205]

Kata kunci: endometriosis, PPARy, two-step RT-qPCR

Correspondence: Adya F Dilmy. Department of Obstetrics and Gynecology, Faculty of Medicine University of Indonesia. Jakarta; email: dido_dilmy@gmail.com

\section{INTRODUCTION}

Endometriosis is an endometrium-like lesion outside of the uterine cavity that is sensitive to the hormonal changes in the menstrual cycle. ${ }^{1,2}$ The prevalence of endometriosis in women of reproductive age is around $10 \%{ }^{3,4}$ This condition is more frequently encountered in women with pelvic pain and infertility, in which $35-50 \%$ have en- dometriosis. $^{2}$ Data from RS Dr. Cipto Mangunkusumo in 2000-2005 showed 111 new cases of endometriosis diagnoses by laparoscopy, $75 \%$ of which are found in women aged 25-39 years. 5,6

Currently, most cases of endometriosis are treated with hormones, that may influence the menstrual cycle and fertility of the patients. ${ }^{1,7}$ Nonhormonal treatments such as NSAID (non-steroidal 
anti-inflammatory drugs) do not interfere with fertility, but long-time treatment with such agents may pose significant side effects. ${ }^{1,2,7}$ A non-hormonal treatment that can be used for a long period without significant side effects and with no impact on fertility is urgently needed for endometriosis patients who wish to conceive. Understanding the pathogenesis of endometriosis may open doors to other treatment modalities, either by methods that are already available or under development.,3,7-9

One agent that may be used as a modulator is the activation of PPARy receptor, which is widely recognized in the treatment of diabetes. ${ }^{3,10}$ The potential role of PPARy in the pathogenesis of endometriosis and as an alternative non-hormonal treatment encouraged us to study the profile of PPARy receptors in patients with endometriosis.

Researchers have widely known that activation of PPARy influences the differentiation of adipocytes and insulin resistance. ${ }^{11}$ PPARy may also influence the production of proinflammatory cytokines by systemic immune cells and cells in peritoneal fluids, acting as an external factor to the development of endometrial tissue in the peritoneum. ${ }^{12-16}$ Development in the last decade showed that PPARy may effect the profile of certain genes in eutopic and ectopic endometrium. ${ }^{17,18}$ These facts encouraged us to conduct a research, to find differences between the profile of PPARy genes in eutopic and ectopic endometrium and to elaborate the role of PPARy in the development of local endometriosis tissue.

Significant gene profile differences have been identified in eutopic and ectopic endometriosis tissue. ${ }^{19-21}$ Several studies have revealed higher aromatase profiles in the nucleus of ectopic glandular endometrium compared to eutopic endometri-

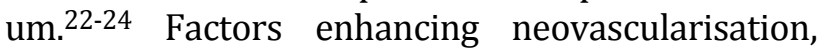
VEGF, and adhesion factors, CAM, are also more abundant in ectopic endometrium. ${ }^{25,26}$ The profile of apoptosis-regulator genes, $\mathrm{Bcl}-2$ and Bax, are also different in eutopic and ectopic endometrium. ${ }^{27}$

Administration of PPARy ligands may inhibit adhesion of endometrial cells to the peritoneum by reducing the expression of ICAM-12.28,29 The influence of PPARy on implants and neovascularization is proven by reduced VEGF activity, thus inhibiting neovascularization. ${ }^{19}$ Activation of PPARy also reduces aromatase, thus reducing the production of estrogen in endometriosis lesions and reducing the proliferation of endometriosis lesions in vitro. ${ }^{30}$ One study also reported reduction of anti-apoptotic genes in endometriosis lesions which had PPARy ligands administered. ${ }^{31}$

Administration of PPARy ligand agonists in animal with endometriosis also reduced the size and mass of ectopic endometrium..$^{32}$ In baboons, it reduced the size and area of pelvic endometriosis. ${ }^{33}$ In humans, administration of PPARy agonists reduced pain symptoms. ${ }^{35}$ It has been reported that increased PPARy expression (determined through immunohistochemistry) in peritoneal lesions reduced symtomps in endometriosis patients, especially pelvic pain, dysmenorrhea, and dyspareunia. ${ }^{34,35}$

The role of PPARy is determined by both the availability of ligands and expression of its receptor. ${ }^{32-35}$ Expression of PPARy receptor in endometriosis tissue may be useful to study its role in the pathogenesis of endometriosis and as a predictor in determining the response to therapy with PPARy ligands. ${ }^{34,35}$ We conducted this study to evaluate the expression of the PPARy and to compare its expression in eutopic and ectopic endometrium in reproductive age women with endometriosis.

\section{METHODS}

This a biomedical science study with cross sectional design, and with numerical comparison between two-paired group analysis. We collected data from February to April 2014. Subjects were recruited from general gynecology patients and patients from the fertility clinic who underwent surgery in the Department of Obstetrics and Gynecology, RS Cipto Mangunkusumo, Jakarta. Samples were analyzed in the Integrated Laboratory, Faculty of Medicine University of Indonesia.

Samples were obtained using endometrial biopsy when subjects were in the operating room. Samples were transported, then total DNA extraction was performed. After that, samples were stored in $-80^{\circ} \mathrm{C}$ until analysis was performed. After all samples were collected, frozen endometrial tissues were thawed, and RT-PCR was conducted to assess the expression of PPARy receptors in the endometrium.

RT-PCR examination of PPARy receptors was initiated by thawing of samples stored in RNA ladder in room temperature, followed by RNA isolation. 
The result of RNA isolation was total RNA of samples in elution buffer solution.

Development of cDNA from total RNA was started by assessment of concentration and purity of RNA by using spectrum analyzer in $260 \mathrm{~nm}$ and $280 \mathrm{~nm}$ wavelength. To assess the expression of PPARy with qPCR, we designed primers in silico (with computers) with IDT (Integrated DNA technologies) software, and we obtained the sequence of target and reference genes.

All qPCR were performed with Rotor Gene $\mathrm{Q}^{\circledR}$ machine. Quantification for each sample was calcu-

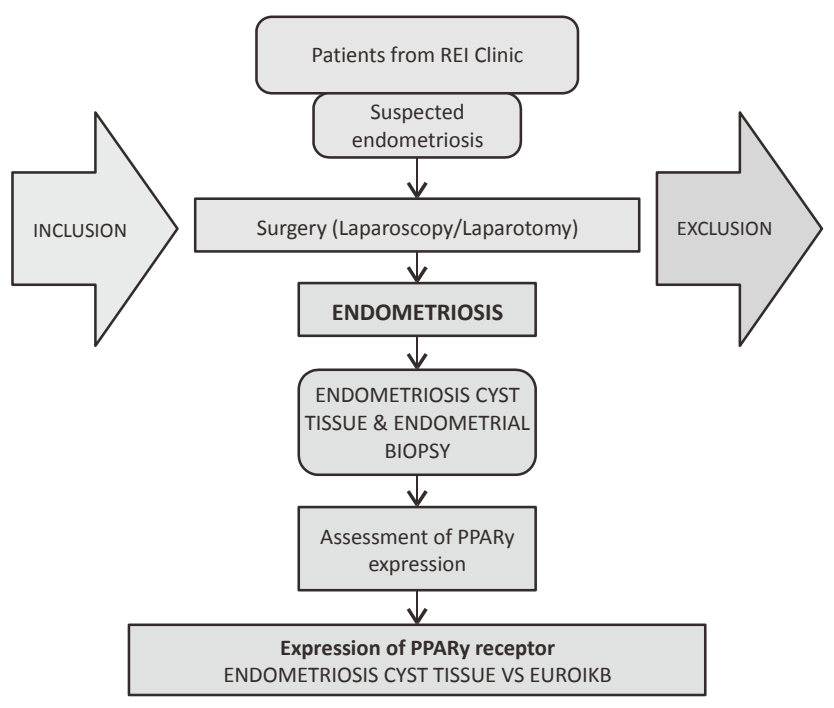

Figure 1. Research workflow.

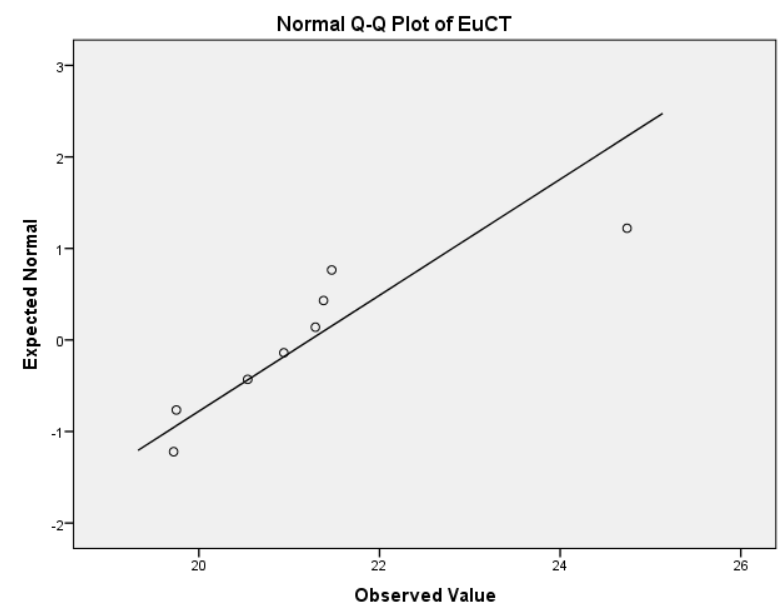

lated by using the CT (Cycle threshold) from target genes (PPARy) and the CT from reference genes (GAPDH). Semiquantification of gene expression was carried out with Livak method. ${ }^{37}$

\section{RESULTS}

We identified 49 patients who underwent surgery for endometriosis cysts from February to April 2014. Eighteen patients were excluded: 12 did not sign the consent form, 2 patients had tubo-ovarial abcess, 2 patients had obesity, and 2 patients were smokers. From the remaining 31 patients, we did not obtain adequate endometrial samples (nil or less than $0.5 \mathrm{ml}$ ). Seventeen patients were adequate for analysis, however to due to limited funds for reagens and material, only 10 patients (20 samples) were analyzed. The remaining 7 pair of samples were stored in $-80^{\circ} \mathrm{C}$ for further studies.

This study included 10 subjects. All subjects underwent surgery for endometriosis cysts. The mean age of patients was $31.8 \pm 4.15$ years, with BMI $22.21 \pm 1.38 \mathrm{~kg} / \mathrm{m}^{2}$, waist-hip ratio $0.81 \pm 0.52$ $\mathrm{cm}$, and mean leukocyte count $8,033 \pm 1,897$. All subjects were stage III-IV endometriosis patients with endometriosis cysts; the mean size of the cysts was $6.8 \pm 2,1 \mathrm{~cm}$ and all subjects experienced menstrual pain with a mean visual analogue scale (VAS) 6.3 \pm 1.15 . It could be concluded that the subjects belonged to a homogenoud group, which is women of reproductive age with menstrual pain and endometriosis cysts, with normal BMI and without other comorbidities.

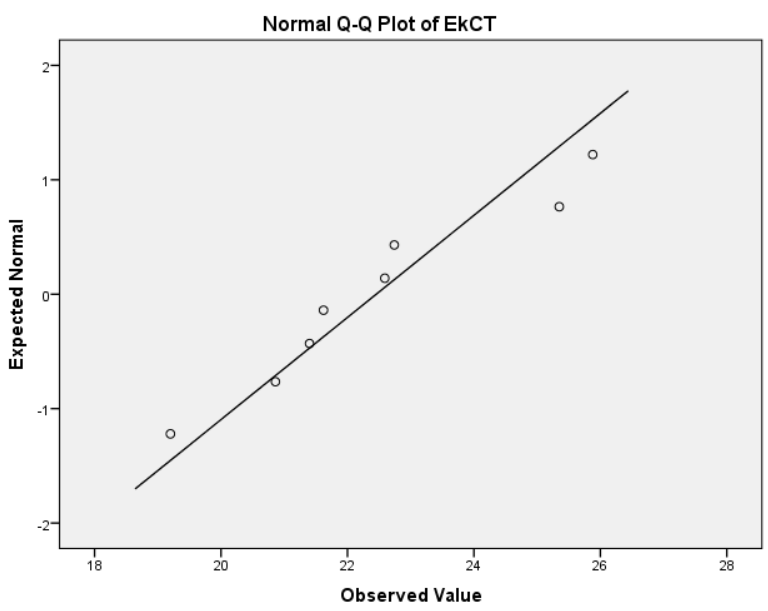

Figure 2. Normality plots of CT (Cycle Threshold) qPCR PPARy in Eutopic (left) and Ectopic Endometrium (right) 
Quanitification of receptor expression was performed with Livak method by using the following formula: $2^{-\Delta \Delta} \mathrm{CT}[\Delta \Delta \mathrm{CT}=\Delta \mathrm{CT}$ - (median CT PPARy median CT GAPDH)]. ${ }^{37}$ The result of this formula is a relative time-fold towards the reference gene (GAPDH), a housekeeping gene whose expression is constant in all tissues.

The mean expression of PPARy in eutopic and ectopic endometrial tissue was $1.16 \mathrm{u}$ and $1.25 \mathrm{u}$, respectively. Normality tests towards the CT (Cycle threshold) data using Kolmogorov-Smirnov and Shapiro-Wilks revealed normal distribution in both groups ( $\mathrm{p}>0.05)$.

As the data was normally distributed and obtained from the same patient (eutopic and ectopic tissue), we conducted a paired t-test to find the difference between both groups. We found that the expression of PPARy in ectopic endometrium was higher than in eutopic endometrium, but the difference was not significantly different (1.25 vs. 1.16, $\mathrm{p}=0.26$ ) (Table 1).

Table 1. Comparison of PPARy Receptor Expression

\begin{tabular}{lccc}
\hline \hline & $\begin{array}{c}\text { Mean PPARy receptor expression } \\
\text { (Unit= relative-folds to GADPH, a reference gene) }\end{array}$ & $\mathbf{p}$ & $\begin{array}{c}\text { Difference } \\
\text { of mean }\end{array}$ \\
\hline $\begin{array}{l}\text { Eutopic } \\
\text { tissue }\end{array}$ & 1.16 & 0.26 & 0.09 \\
$\begin{array}{l}\text { Ectopic } \\
\text { tissue }\end{array}$ & 1.25 & & \\
\hline \hline
\end{tabular}

On Pearson correlation test we found a weak correlation between the expression of PPARy receptor in ectopic endometrium and eutopic endometrium $(r=0.16)$, as shown Table 2 .

Table 2. Correlation between PPARy Expression in Ectopic and Eutopic Endometrium in Endometriosis Patients

\begin{tabular}{lcc}
\hline \hline & Mean & $\mathbf{r}$ \\
\hline $\begin{array}{l}\text { PPARy receptor expression in } \\
\text { eutopic endometrium }\end{array}$ & 1.16 & 0.16 \\
$\begin{array}{l}\text { PPARy receptor expression in } \\
\text { ectopic endometrium }\end{array}$ & 1.25 & \\
\hline \hline
\end{tabular}

\section{DISCUSSION}

MacLaren et al found that PPARy can be found in the reproductive system of mice and bovine. ${ }^{37}$ Pritts et al reported that PPARy was ultimately expressed in the nucleus of cultured endometrial tis- sue. ${ }^{17}$ Peeters et al assessed the expression of PPARy in cultured endometrial cells using immunohistochemistry and RT-PCR, and its effect on administration of PPARy agonists and expression of VEGF. ${ }^{18}$ Until now, no study have assessed the expression of PPARy in ectopic and eutopic endometrial tissue in women with endometriosis and identifying the correlation between both groups.

In this study we obtained the expression of PPARy receptor in eutopic and ectopic endometrium in patients with endometriosis, which indicates that the PPARy ligand may directly influence endometrial tissue or locally, and may be the background for the administration of PPARy agonists in patients with endometriosis. Ohama et al found that administration of PPARy agonistsmay lower TNFy and IL-8 in endometrial tissue. ${ }^{38}$ Lebovic et al proved that PPARy agonists significantly reduce the size of endometriosis lesions in mice and primates. ${ }^{32,33}$ One of the possible mechanism for their findings are through the role of PPARy receptors in target tissue (eutopic and ectopic endometrium), as we have found in this study.

This study also revealed that the expression of PPARy receptors in eutopic and ectopic endometrium was not significantly different $(p>0.05)$, which shows a correlation between the profile of eutopic and ectopic endometrial tissue. This is in line with other studies stating that endometriosis is a disease of eutopic endometrium. ${ }^{19,20}$ Afshar et al found that gene expression abnormalities in eutopic endometrium may influence the behaviour of ectopic endometrium in primates. ${ }^{19}$ Furthermore, Sha et al discovered that gene expression abnormalities identified by qPCR in eutopic endometrium of endometriosis patients compared to endometrium in patients without endometriosis may lead to the survival of endometrium undergoing retrograde menstruation. ${ }^{20}$ Wren et al also concluded from 562 genes analyzed with microarray from several studies, that there are multiple correlations between expression of those genes in eutopic and ectopic endometrium. ${ }^{21}$ Beside our study, until now there has been no study assessing the expression of PPARy receptors in eutopic and ectopic endometrium.

We found a positive weak correlation between expression of PPARy receptor in eutopic and ectopic endometrium of endometriosis patients $(\mathrm{r}=0.16)$. This shows that only $16 \%$ of PPARy receptor expression in eutopic or ectopic endome- 
trium can be predicted from the PPARy receptor expression in their counterparts in patients with endometriosis. This means that the expression of PPARy in eutopic endometrium samples did not entirely represent its expression in ectopic endometrium samples, and vice versa. A further study on PPARy receptor expression in endometrial samples from subjects without endometriosis is needed to evaluate the correlation between PPARy receptor expression in eutopic and ectopic endometrium of endometriosis patients and patients without endometriosis.

\section{CONCLUSION}

Expression of PPARy receptor in eutopic and ectopic endometrial tissue was not significantly different. Therefore, we can conclude that eutopic and ectopic endometrial tissue in endometriosis patients have several similarities. This also means that PPARy receptor may have a role in the pathophysiology of endometriosis in eutopic endometrium of endometriosis patients.

Our results also demonstrates the potential role of PPARy in the pathophysiology and pathogenesis of local endometriosis in endometriosis lesions and eutopic endometrium of endometriosis patients. Knowledge on pathophysiology of endometriosis is essential to understand the pathogenesis, diagnosis, and treatment of endometriosis. Each study trying to solve the puzzle of endometriosis may further the progress towards the understanding of endometriosis.

This study could be continued with samples from patients without endometriosis as the control group, if it is ethically approved. Further studies using samples from various endometriosis samples such as superficial lesions, deeply infiltrating endometriosis, and from endometriosis patients with various stages of endometriosis could also provide significant data on cracking the puzzle of endometriosis.

\section{REFERENCES}

1. Taylor RN, Lebovic DI. Endometriosis. In: Yen and Jaffe's reproductive endocrinology. $6^{\text {th }}$ ed. Philadelphia: W.B. Saunders; 2009: 691.

2. Jacoeb TZ. Pengertian endometriosis. In: Jacoeb TZ, Hadisaputra W, editors. Penanganan Endometriosis: Panduan Klinis dan Algoritme. Jakarta: Sagung Seto; 2009.

3. Bulun SE. Endometriosis. N Engl J Med 2009; 360(3): 268-7.
4. Houston DE, Noller KL, Melton LJ 3rd, et al. Evidence for the risk of pelvic endometriosis by age, race and socioeconomic status. Am J Epidemiol 1987; 125(6): 959-69.

5. Jacoeb TZ. Endometriosis sebagai Tantangan untuk Peningkatan Mutu Reproduksi Manusia. Pidato Pengukuhan Guru Besar. Jakarta: Fakultas Kedokteran Universitas Indonesia; Juli 2007.

6. Puspasari B. Karakteristik pasien endometriosis di Rumah Sakit Dr. Cipto Mangunkusumo selama periode 1 Januari 2000 - 31 Desember 2005. (Tesis). Jakarta: Universitas Indonesia; 2006.

7. Carr BR. Endometriosis. In: Schorge J, Schaffer J, Halvorson $\mathrm{L}$, et al (editors). Williams Gynecology. New York: The McGraw-Hills Companies; 2008: 476-514.

8. Giudice LC, Kao LC. Endometriosis. The Lancet 2004; 364(9447): 1789-99.

9. Kyama C, Mihalyi A, Simsa P. Non-steroidal targets in the diagnosis and treatment of endometriosis Cur Med Chem 2008; 15(10): 1006-17.

10. Froment P, Gizard F, Defever D, et al. Peroxisome proliferator-activated receptors in reproductive tissues: from gametogenesis to parturition. J Endocrinol 2006; 189(2): 199-209.

11. Klimcakova E, Moro C, Mazzucotelli A, et al. Profiling of adipokines secreted from human subcutaneous adipose tissue in response to PPAR agonists. Biochem Biophys Res. 2007; 358(3): 897-902

12. Lebovic DI, Mueller MD, Taylor RN. Immunobiology of endometriosis. Fertil Steril 2001; 75(1): 1-10.

13. Kyama CM, Debrock S, Mwenda JM, et al. Potential involvement of the immune system in the development of endometriosis. Reprod Biol Endocrinol 2003; 1: 123.

14. Harada T, Iwabe T, Terakawa N. Role of cytokines in endometriosis. Fertil Steril 2001; 76(1): 1-10.

15. Saad A. Endometriosis. 2008; 18(5): 126-33.

16. Taylor R, Hornung D, Mueller M. Immunology of endometriosis. In: Arici A (ed). Infertil Reprod Med Clin N Amer. Philadelphia: WB Saunders. 2002: 145-57.

17. Pritts EA, Zhao D, Ricke E, et al. PPAR-gamma decreases endometrial stromal cell transcription and translation of RANTES in vitro. J Clin Endocrinol Metab 2002; 87(4): 1841-4.

18. Peeters LL, Vigne JL, Tee MK, et al. PPAR gamma represses VEGF expression in human endometrial cells: implications for uterine angiogenesis. Angiogenesis 2005; 8(4): 373-9.

19. Afshar Y, Hastings J, Roqueiro D. Changes in eutopic endometrial gene expression during the progression of experimental endometriosis in the baboon. Biol Reprod 2013; 88(2): 1-9.

20. Sha G, Wu D, Zhang L. Differentially expressed genes in human endometrial endothelial cells derived from eutopic endometrium of patients with endometriosis compared with those from patients without endometriosis. Hum Reprod Update 2007; 22(12): 3159-69.

21. Wren J, Wu Y. A system-wide analysis of differentially expressed genes in ectopic and eutopic endometrium. Hum Reprod 2007: 22(8): 2093-102.

22. Noble L, Takayama K, Zeitoun K. Prostaglandin E2 stimulates aromatase expression in endometriosis-derived stromal cells. J Clin Endocrinol 1997; 82(2): 600-6. 
23. Hudelist G, Czerwenka, K., Keckstein, J. Expression of aromatase and estrogen sulfotransferase in eutopic and ectopic endometrium: evidence for unbalanced estradiol production in endometriosis. Reprod Sci 2007; 14(8): 198-805.

24. Velasco I, Rueda J, Acién P. Aromatase expression in endometriotic tissues and cell cultures of patients with endometriosis. Mol Hum Reprod 2006; 12(6): 377-81.

25. Kressin P, Wolber EM, Wodrich H. Vascular endothelial growth factor mRNA in eutopic and ectopic endometrium. Fertil Steril 2001; 76(6): 1220-4.

26. Viganò $P$, Gaffuri $B$, Somigliana E. Expression of intercellular adhesion molecule (ICAM)-1 mRNA and protein is enhanced in endometriosis versus endometrial stromal cells in culture. Mol Hum Reprod 1998; 4(12): 1150-6.

27. Meresman G, Vighi S, Buquet R. Apoptosis and expression of Bcl-2 and Bax in eutopic endometrium from women with endometriosis. Fertil Steril 2000; 74(4): 760-6.

28. Kavoussi S, Witz C, Binkley N. Peroxisome-proliferator activator receptor-gamma activation decreases attachment of endometrial cells to peritoneal mesothelial cells in an in vitro model of the early endometriotic lesion Mol Hum Reprod 2009; 15(10): 687-92.

29. Platteeuw L, D'Hooghe, T. Novel agents for the medical treatment of endometriosis. Curr Opin Obstet Gynecol 2014; 26(4): 243-52.

30. Kavoussi S, Arosh J, Lee J. PPAR-gamma ligand activation decreases p450 aromatase gene expression in human endometriotic epithelial and stromal cells in vitro. Fertil Steril 2009; 92(3): 12.
31. Wu Y, Guo S. Peroxisome proliferator-activated receptorgamma and retinoid $\mathrm{X}$ receptor agonists synergistically suppress proliferation of immortalized endometrial stromal cells Fertil Steril 2009; 91(5): 2142-7.

32. Lebovic DI, Kir M, Casey CL. Peroxisome proliferator-activated receptor-gamma induces regression of endometrial explants in a rat model of endometriosis. Fertil Steril 2004; 82: 1008-13.

33. Lebovic DI, Mwenda JM, Chai DC, et al. PPAR-gamma receptor ligan induces regression of endometrial explants in baboons: A prospective, randomized, placebo- and drug-controlled study. Fertil Steril 2007; 88: 1108-19.

34. Moravek MB, Ward EA, Lebovic DI. Thiazolidinediones as therapy for endometriosis: a case series. Gynecol Obstet Invest 2009; 68(3): 167-70.

35. McKinnon B, Bersinger NA, Huber AW, et al. PPAR-[gamma] expression in peritoneal endometriotic lesions correlates with pain experienced by patients. Fertil Steril 2010; 93(1): 293-6.

36. Livak K. Analysis of relative gene expression data using realtime quantitative PCR and the 22DDCT method. Methods 2000; 25: 401-7.

37. MacLaren L, Guzeloglu A. Peroxisome proliferator-activated receptor (PPAR) expression in cultured bovine endometrial cells. Domestic Animal Endocrinol 2003; 30: 155-69.

38. Ohama Y, Harada T, Iwabe T, et al. Peroxisome proliferator-activated receptor-gamma ligan reduced tumor necrosis factor-alpha-induced interleukin-8 production and growth in endometriotic stromal cells. Fertil Steril 2008; 89(2): 311-7. 